\title{
Formulation of Foot Lotion Containing Papaya Leaf Extract (Carica Papaya L.) With Tri Ethanol Amine Concentration Variation as
} Emulgator and Its Physical Stability

\author{
$1^{\text {st }}$ Dewi Marlina \\ Pharmacy \\ Poltekkes Kemenkes Palembang \\ Palembang, Indonesia \\ dewimarlina@poltekkespalembang.ac.id \\ $3^{\text {rd }}$ Diah Febrihaq \\ Pharmacy \\ Poltekkes Kemenkes Palembang \\ Palembang, Indonesia \\ febrihaq99@gmail.com
}

$2^{\text {nd }}$ Rian Trias Widyani

Pharmacy

Poltekkes Kemenkes Palembang

Palembang, Indonesia

riantrias@gmail.com

$4^{\text {th }}$ Tari Janesa Karunia

Pharmacy

Poltekkes Kemenkes Palembang

Palembang, Indonesia

tarijanesa2@gmail.com

Corresponding author: dewimarlina@poltekkespalembang.ac.id

\begin{abstract}
Foot heel is very susceptible to Xerosis due to lack of moisture due to loss of lipids and natural moisturizing factors in the Stratum Corneum. According to research, Papaya Leaves (Carica papaya L) contain phenol compounds which are secondary metabolites which play an active role as antioxidants and antimicrobials. This study aims to examine whether papaya leaf extract (Carica papaya L) can be formulated as a Foot Lotion by varying the concentration of Triethanolamine as an emulgator and performing a physical stability test. This study uses an experimental method. Papaya leaf extract (Carica papaya L) as much as $10 \%$ as the active ingredient and vary Triethanolamine as an emulgator with a concentration of $3 \%$ in formula I; 3.5\% in formula II; and 4\% in formula III. Then a 28-day preparatory evaluation was made that the $\mathrm{pH}$ results of foot lotion preparations with formula III were more stable than formulas I and II while the results of the viscosity of all formulas were required. All formulas increase and decrease in the spread diameter in each week but remain in the range of $5-7 \mathrm{~cm}$ and do not change color, smell and do not irritate the skin. Judging from the spread, homogeneity, color, odor and skin irritation, the three formulas met the requirements for 28 days of storage. Papaya leaf extract (Carica papaya $L$ ) can be formulated into a stock of lotion that is stable and meets the requirements. The most stable footlotion formula is formula II with a variation of $3.5 \%$ Trietanolamine concentration.
\end{abstract}

Keywords-footlotion, papaya leaf extract (Carica papaya L), Formulation Triethanolamine

\section{INTRODUCTION}

Dry skin is often taken lighty by some people. However, this is a serious condition and many people complain about that because it can be disturbing their looks. The increase of Tran Epidermal Water Loss (TEWL) which causes dry skin is due to skin disorders which cause a lot of water to evaporate into the atmosphere [1]

Foot heelis particularly susceptible to xerosis due to lack of moisture due to loss of lipids and natural moisturizing factors in the stratum corneum. The symptoms of xerosis of foot heel is shown dryness that surface of skin becoming scaly, hard, and discomfort [2]. The solution of this problem is use of a moisturizer which functions to keep the skin moist and makes the skin softer and use some cosmetic that can stabilize the lipids on the foot heel.

\section{A. Lotion}

One of the cosmetic remedies that can be used to resolve this problem is Lotion. Lotion is a cosmetic preparation of emollients (softeners) that contain a lot of water. This preparation has several properties, as a source of moisture for the skin, gives a layer of oil that is almost the same as sebum, makes the hands and body become soft, but does not feel oily and easy to apply [3]. 


\section{B. Papaya Leaf Ingredients}

The natural active ingredients of Papaya (Carica papaya L.) that can be used as health care products, cosmetics and prevention of disease. It was reported that the plant has chemical content, that is alkaloids, saponins and flavonoids in the leaves, roots and bark of the stems, containing polyphenols in the leaves and stems [4]. Maisarah in 2013 also stated that antioxidant activity was related to phenolic and flavonoid levels. Then the best antioxidant activity of Papaya leaf methanol extract (Carica papaya L) lies in early leaf extract of papaya. Phenolic is the main compound that has antioxidant activity by neutralizing lipids from free radicals and preventing the decomposition of hydroperoxid into free radicals, while flavonoids have hydroxyl groups that can donate electrons and act as free radical scavengers [5].

\section{METHOD}

\section{A. Materials}

The materials used are cetyl alcohol, stearic acid, adepslanae, triethanolamine, glycerin, propyl paraben, methyl paraben, greentea essence, aqua dest, early leaves of papaya, methanol [6].

\section{B. Papaya Leaf Extract Manufacturing}

Early leaves of papaya cleaned of impurities and washed using water. A total of $3 \mathrm{~kg}$ of wet papaya leaves were airdried, so that 800 grams of dried papaya leaf simplicity were obtained and then macerated with methanol solvent for 3-5 days. Then in vacuum distillation which produces a thick papaya leaf extract as much as 146.6 grams [7].

\section{Formulation Preparation}

The ingredients of the oil phase (cetyl alcohol, stearic acid, adepslanae, and propyl paraben) are melted on a water bath at $750 \mathrm{C}$ using a evaporating dish and the water phase (glyceryl, triethanolamine, methyl paraben, greentea essence, thick papaya leaf extract) is dissolved with hot water at the same temperature. After that, mix the oil phase and water phase in a mortar while continuing stir until it becomes a homogeneous lotion preparation [8].
Table 1. Foot lotion formulation with Papaya leaf extract Carica

\begin{tabular}{|c|c|c|c|c|}
\hline & \multicolumn{3}{|c|}{ Jumlah Yang Digunakan } & Keterangan \\
\hline Bahan & Formula I & $\begin{array}{c}\text { Formula } \\
\text { II }\end{array}$ & $\begin{array}{c}\text { Formula } \\
\text { III }\end{array}$ & \\
\hline $\begin{array}{l}\text { Ekstrak Daun } \\
\text { Pepa ya (Cari } \\
\text { ca papaya }\end{array}$ & - & - & - & Bahan Aktif \\
\hline Setil Alkohol & $6 \%$ & $6 \%$ & $6 \%$ & Emulsi fying agent \\
\hline Asam Sterat & $6 \%$ & $6 \%$ & $6 \%$ & Emulsi fying agent \\
\hline Lano lin & $6 \%$ & $6 \%$ & $6 \%$ & Emulsi fying \\
\hline TEA & $3 \%$ & $3,5 \%$ & $4 \%$ & $\begin{array}{c}\text { Emulsi fying agent, } \\
\text { Pemba } \\
\end{array}$ \\
\hline Glise rin & $3 \%$ & $3 \%$ & $3 \%$ & Humektan \\
\hline $\begin{array}{l}\text { Propi len Parab } \\
\text { en }\end{array}$ & $0,02 \%$ & $0,02 \%$ & $0,02 \%$ & Pengawet \\
\hline Metil Parab en & $0,18 \%$ & $0,18 \%$ & $\begin{array}{c}0,18 \\
\%\end{array}$ & Pengawet \\
\hline $\begin{array}{l}\text { Greentea } \\
\text { Essens }\end{array}$ & q.s & q.s & q.s & Pengaroma \\
\hline Aqua dest & Ad 100 & Ad 100 & Ad 100 & Pembawa \\
\hline
\end{tabular}

\section{Physical Evaluation of Papaya Extract Foot Lotion}

1. Organoleptic Test

Organoleptic testing of papaya leaf extract lotion (Carica papaya L.) was carried out by observing the texture, discoloration, and aroma of the lotion.

\section{Homogeneity Test}

The homogeneity test of the papaya leaf extract lotion was carried out by taking a small sample of the lotion formula, then put a little lotion between the two glass slides. The arrangement of coarse or inhomogeneous particles is observed.

\section{3. pH Test}

The $\mathrm{pH}$ test was carried out by preparing each sample of the lotion preparation. The electrodes are dipped in the lotion until the $\mathrm{pH}$ meter shows a steady reading. Then write the scale of $\mathrm{pH}$.

4. Spreadability Test

Testing the spreadabilitytest by taking a lotion as much as 0.5 grams and put it in the middle of the watch glass. Take another round glass and place it on top of the lotion and let it sit for 1 minute, then the diameter of the distribution is recorded.

5. Viscosity Test

The viscosity test used a Brookfield Viscosimeter with spindle number 1 and a speed of $100 \mathrm{rpm}$. The spindle was placed in the middle of a bowl filled with lotion. Observe the visicosity needle. Once stable, then read on the scale that showed on the viscometer. 


\section{Skin Irritation Test}

The skin irritation test for foot lotion was carried out by way of lotions that had been stored for 28 days and rubbed on the backs of the hands, a total of 30 responses were observed. Symptoms of redness, feeling hot and sore on the skin were observed after applying lotion containing papaya leaf extract with variations in the concentration of Triethanolamine which was stored for 28 days.

\section{RESULT}

Papaya leaf methanol extract (Carica papaya L.) is formulated into lotion as an antioxidant. The lotion base consists of two phases, that is the oil phase and the water phase, which can be mixed with the addition of an emulsifier (elmugator). The desired lotion in the formulation is the M / A type lotion which is easier to clean and wash because of its hydrophilic outer phase characteristics [7].

Fig. 1. Foot lotion papaya leaf extract preparation

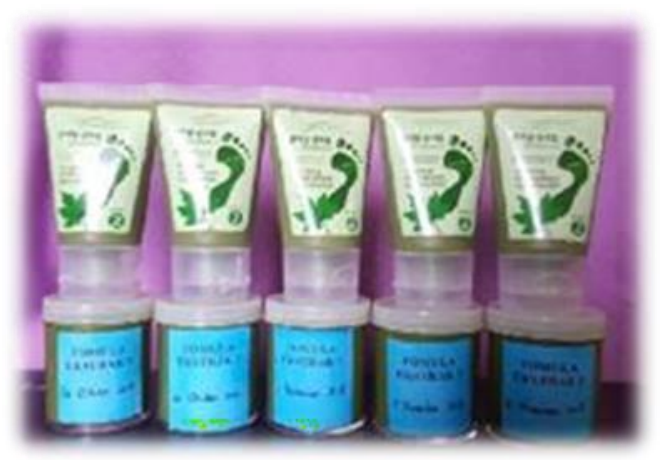

Organoleptic observations carried out about visual observations of texture, color, smell. Organoleptic observations showed that the color and odor of the base and the three formulas after 28 days of storage did not change.

The homogeneity test is the distribution of the dispersed phase in the dispersing material, the absence of secondary particle aggregation, equally and regular distribution of the dispersed phase and the refinement of large primary particles. The homogeneity test results show that all formulas have homogeneous characteristics even though they have been stored for 28 days. It is said to be homogeneous because at the time of the test there were no coarse particles or lumps, lotions were evenly mixed and show the same color.
Fig. 2. pH test result of foot lotion papaya leaf extract

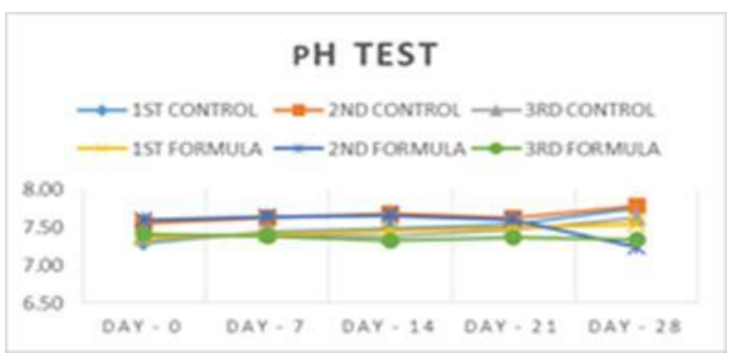

Foot lotion of papaya leaf methanol extract (Carica papaya L.) for 28 days of storage show increase the scale $\mathrm{pH}$, this was probably due to the influence of environmental conditions such as light and temperature changes during storage and as the time when evaluating the preparation[2].

The difference in the $\mathrm{pH}$ of the formula is due to the difference in the use of TEA as a neutralizer for stearic acid, but in this case it is proven that the more TEA is used, the higher the $\mathrm{pH}$ produced.

Fiq. 3.Spreadability test result

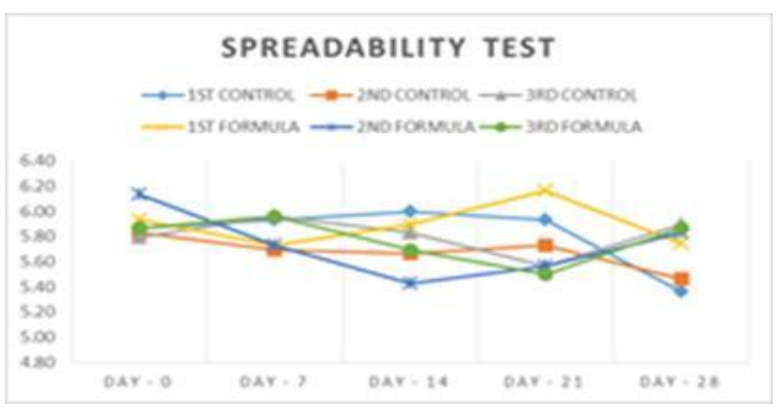

From the results of observations and measurements of the stability of the spreadability of the foot lotion of the methanol extract of Papaya leaves (Carica papaya L.), all formulas had a decrease in diameter each week, but in this caseall the dispersion diameter for foot lotion preparations still meet the requirements where the standard spreadability for lotions is $5-7 \mathrm{~cm}$ [8] [9]. The spreadability is influenced by the viscosity which also increases.

Fiq. 4. Viscosity test result

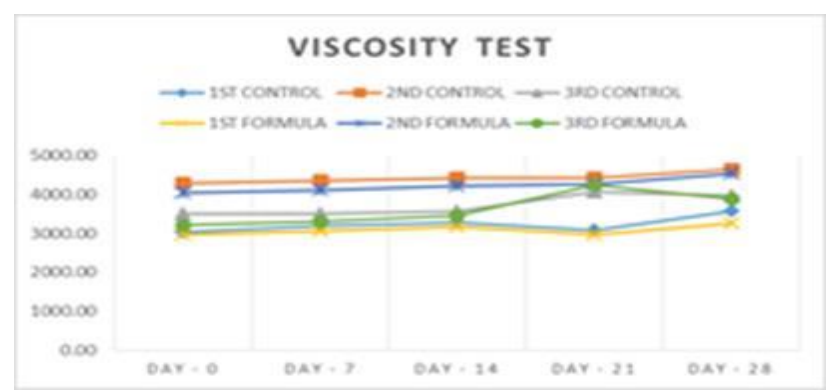


From the observations and measurements of the viscosity stability of the methanol extract of Papaya leaf (Caricapapaya L.) foot lotion, there is a difference in the average viscosity results between formula I, formula II, and formula III. This difference can be caused by several factors such as the influence of temperature, storage area and the process of weighing, manufacturing or evaluating the methanol extract of Papaya leaf (Carica papaya L.) foot lotion. In the evaluation process, if a viscosity is significantly different from the average, the preparation should be left to stand for 2-3 hours with the intention of making the preparation back to normal. The results of the lotion viscosity test showed that the entire formula entered the viscosity range of the lotion, namely 2000-50000 cp. Thus, in terms of testing and observation of the viscosity of the foot lotion of papaya leaf methanol extract (Carica papaya L.), it has according the requirements to be formulated into a lotion dosage form.

\section{Table 2. Skin irritation test result of papaya leaf extract foot} lotion

\begin{tabular}{|c|c|c|c|c|}
\hline \multirow{2}{*}{ Foor Lorion } & \multicolumn{2}{|c|}{ Physical Stability } & \multicolumn{2}{c|}{ Percentage } \\
\cline { 2 - 5 } & \multicolumn{2}{|c|}{ Result } & \multicolumn{2}{c|}{ Result } \\
\cline { 2 - 5 } & Imitate & $\begin{array}{c}\text { Do not } \\
\text { irritae }\end{array}$ & Irritate & $\begin{array}{l}\text { Do not } \\
\text { imritate }\end{array}$ \\
\hline Formula I & 0 & 30 & 0 & $100 \%$ \\
\hline Formala II & 0 & 30 & 0 & $100 \%$ \\
\hline Formula III & 1 & 29 & $3.33 \%$ & $96.67 \%$ \\
\hline
\end{tabular}

From the results of observations made by 30 respondents, there were $3.33 \%$ of respondents said that the preparations in the 3rd formulation irritated the skin, but for the 1 st and 2 nd formulations, no respondents said that there were symptoms of skin irritation after application. the lotion will qualify if it is not irritating and does not complete the requirements if it is irritating.[4] Although some respondents stated that there was a change in color in lotion preparations stored at room temperature, this was not very significant because respondents stated that the change in odor did not exceed $50 \%$. the data category which amounts to more than $50 \%$ in the percentage analysis is often called the majority. Thus, it can be concluded that all foot lotions are non-irritating and qualify.[10].

\section{CONCLUSION}

The methanol extract of papaya leaves (Carica papaya L.) can be formulated in foot lotion dosage form and complete the evaluation requirements after storage for 28 days.

\section{ACKNOWLEDGMENT}

Thanks to the DIPA funding for the Research and Development Unit of the Health Polytechnic of the Ministry of Health in Palembang as a provider of research funds through the 2018 PKM-P Research Grant.

\section{REFERENCES}

[1] Alorkpa EJ, Boadi NO, Badu M, Saah SA. Phytochemical Screening, Antimicrobial And Antioxidant Properties Of Assorted Carica Papaya Leaves In Ghana. J Med Plants Stud 2016;4:193-8.

[2] Foyzun T, Aktar K. Comparison And Evaluation Of Total Phenolic, Flavanoid Content And Antioxidant Activity Of Crude Methanol And Ethyl Acetate Extracts Of Carica Papaya Leaves. J Pharmacogn Phytochem 2017;6:117-24.

[3] Megantara INAP, Megayanti, K, Wirayanti R, Esa IBD, Wijayanti NPAD, Yustiantara P. Formulasi Lotion Ekstrak Buah Raspberry(Rubus Rosifolius) Dengan Variasi Konsentrasi Trietanolamin Sebagai Emulgator Serta Uji Hedonik Terhadap Lotion. J Jarm Udayana 2017:1. Https://Doi.Org/10.24843/Jfu.2017.V06.I01.P01.

[4] Elisa Friska Romasi*), Jessica Karina And AJNP, Department. Antibacterial Activity Of Papaya Leaf Extracts Against Pathogenic Bacteria. Makara J Technol 2013;15:173. Https://Doi.Org/10.7454/Mst.V15i2.936.

[5] Ferrarini M, Moretta L, Abrile R, Durnte ML. Receptors For Igg Molecules On Human Lymphocytes Forming Spontaneous Rosettes With Sheep Red Cells. Eur J Immunol 1975;5:70-2. Https://Doi.Org/10.1002/Eji.1830050115.

[6] Mandal S De, Mathipi V, Lalnunmawii E. An Investigation Of The Antioxidant Property Of Carica Papaya Leaf Extracts From Mizoram, Northeast India. Res Rev J Bot Sci 2015;4:42-5.

[7] Rahmawati F, Yetti OK. ( Carica Papaya L ) MENGGUNAKAN BASIS HIDROKARBON. J Pharm Sci 2014:19-26.

[8] Syarifah RS, Mulyanti D, Gadri A. Formulasi Sediaan Masker Gel Peel-Off Ekstrak Daun Pepaya (Carica Papaya L.) Sebagai Antijerawat Dan Uji Aktivitasnya Terhadap Bakteri Propionibacterium Acnes. Pros Penelit Spes Unisba 2015 2015:662-70.

[9] Ruswanti Eka Oktavia , Cholil SBI. Efektivitas Ekstrak Etanol Daun Pepaya (Carica Papaya) 100\% Terhadap Waktu Penyembuhan Luka. Dentino J Kedokt Gigi 2014;II:197-200.

[10] Andi. Uji Efektivitas Antioksidan Ekstrak Etanol Daun Pepaya (Carica Papaya L.) Pada Sediaan Krim Terhadap Dpph (1,1-Diphenyl-2- Picrylhydrazil). J Teknol Kim Dan Ind 2014;2:1-7. 